International Journal of Current Advanced Research

ISSN: O: 2319-6475, ISSN: P: 2319 - 6505, Impact Factor: SJIF: 5.995

Available Online at www.journalijcar.org

Volume 6; Issue 4; April 2017; Page No. 3091-3093

DOI: http://dx.doi.org/10.24327/ijcar.2017.3093.0190

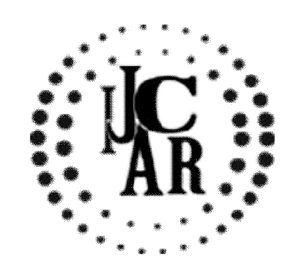

Research Article

\title{
EFFECT OF EXERCISE ON SALIVA FLOW, VISCOSITY AND pH
}

\section{Prema Sivakumar* and Gifrina Jayaraj}

Saveetha Dental College

\begin{tabular}{l}
\hline A R T I C L E I N F O \\
\hline Article History: \\
Received $20^{\text {th }}$ January, 2017 \\
Received in revised form $19^{\text {th }}$ February, 2017 \\
Accepted $23^{\text {rd }}$ March, 2017 \\
Published online $28^{\text {th }}$ April, 2017 \\
\hline
\end{tabular}

Key words:

Saliva Flow, Ph, Viscosity, Exercise

\begin{abstract}
A B S T R A C T
The study was aimed at evaluating the effect of exercise of the various physical characteristics of saliva like salivary flow, $\mathrm{pH}$ and viscosity. Saliva has a protective function on teeth. After an intense workout, there are various changes in saliva: hormonal molecular and physical, which can be evaluated to reveal the change in salivary composition and nature which may predispose to plaque development and dental caries. 30 healthy people, picked randomly, had an intense workout in the gym, for half an hour. Saliva was collected before and after exercise, and tested for the three parameters, namely, salivary flow, $\mathrm{pH}$ and viscosity. The time for salivary flow ( $\mathrm{t}$ test) increased after exercise, the $\mathrm{pH}$ (t test) was decreased and the results were not statistically significant for the viscosity of the saliva (chi square tests).
\end{abstract}

Copyright $(2017$ Prema Sivakumar and Gifrina Jayaraj. This is an open access article distributed under the Creative Commons Attribution License, which permits unrestricted use, distribution, and reproduction in any medium, provided the original work is properly cited.

\section{INTRODUCTION}

Saliva is a watery fluid, secreted into the mouth by salivary glands and it has various functions, few of which are to facilitate taste, to chew and swallow, to lubricate and moisten the mouth and initiate starch digestion. Workouts impact every system of the body, like blood flow, metabolism and chemical levels with some effects, lasting longer than the others. Sometimes it can even result in chronic adaptations. [1] It leads to various changes in the brain altering the hormone and metabolite levels. Over a period of time blood volume and cardiac output increase. [2][3] Saliva collection is hassle free and non-invasive, and can provide information on various physical and chemical parameters, without the potentially harmful consequences of other samples like arterial or venous samples and tissue biopsies.[4] With an increased intensity of exercise, the salivary protein secretion is increased, which leads to increased viscosity. [5, 6, 7, 8, 9] The salivary secretion is controlled by sympathetic (viscid saliva with increased protein levels) and parasympathetic (watery clear saliva) innervation.[10,11] The increased viscosity of saliva after exercise can be attributed to dehydration, increased concentration of proteins and mucins, and due to evaporation of saliva owing to mouth breathing.[12]

\section{MATERIALS AND METHODS}

A study was performed among 30 healthy individuals, picked randomly, without any systemic complications.

\section{*Corresponding author: Prema Sivakumar}

Saveetha Dental College
The saliva samples were collected with informed consent before and after an intense gym workout. The parameters recorded were saliva flow, viscosity and $\mathrm{pH}$.

\section{Flow}

The time taken for the droplets of saliva to form in the minor salivary glands (lower labial) after being blotted dry with a piece of gauze, was recorded with a timer.

\section{Viscosity}

The saliva was collected in a collecting cup, and categorised into one of the following groups:

Watery clear, bubbly frothy and sticky frothy (with deposits) $\mathrm{pH}$ :

The saliva in the collecting cup was examined for the $\mathrm{pH}$ by dipping a $\mathrm{pH}$ paper into it for $10 \mathrm{~s}$, and the colour change was visually recorded by comparing it with the $\mathrm{pH}$ chart.

All the above parameters were recorded in the samples collected before and after the exercise session, by the same individual. The data was analysed using SPSS software. The tests used were paired sample t-test (for $\mathrm{pH}$ and flow rate) and chi square tests. Statistical significance is set at $<0.05$

\section{RESULTS}

The results of the study conducted are as follows:

Flow

The average time for salivary flow increased from $13.56 \mathrm{~s}$ to $26.20 \mathrm{~s}$, after exercise. In the paired sample t-test, the results were highly significant $(\mathrm{p}=0.000)$ 
$\mathrm{pH}$ :

The average $\mathrm{pH}$ increased decreased from 6.88 to 6.48 , and in the paired sample $t$ test, the results were significant $(\mathrm{p}=0.002)$

\section{Viscosity}

The results from the pearson chi square tests were not significant $(p=0.459)$, and the results from McNemar-Bowker Test were slightly significant $(\mathrm{p}=0.035) 80 \%$ of the samples had sticky frothy saliva after exercise.

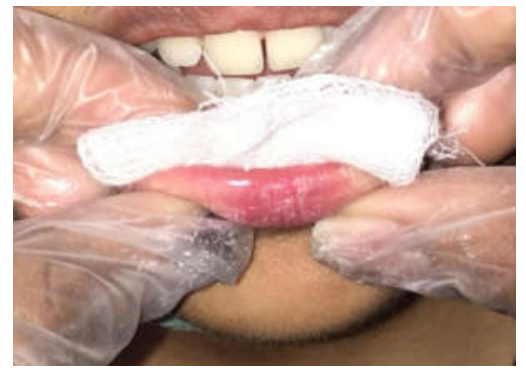

Fig 1 blotting the lower lips dry with gauze

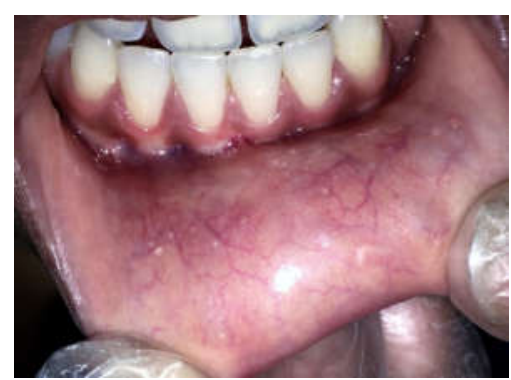

Fig 2 drops of saliva observed on the lower lips formed from the minor salivary glands

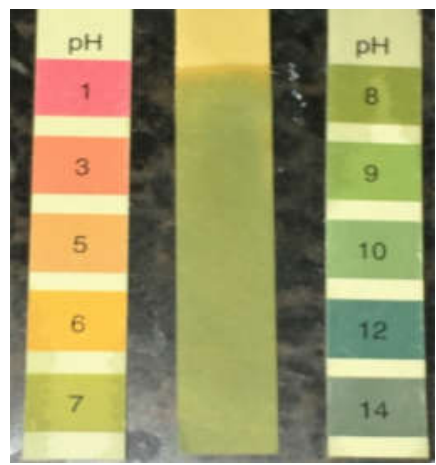

Fig $3 \mathrm{pH}$ paper dipped in salivary sample compared with the colour comparators

\begin{tabular}{|c|c|c|c|c|c|}
\hline & & Mean & $\mathrm{N}$ & Std. Deviation & $\begin{array}{l}\text { Std. Error } \\
\text { Mean }\end{array}$ \\
\hline \multirow[t]{2}{*}{$\begin{array}{l}\text { Pair } \\
1\end{array}$} & $\begin{array}{l}\text { Flow(seconds) - } \\
\text { Before Exercise }\end{array}$ & 13.56 & 25 & 5.945 & 1.189 \\
\hline & $\begin{array}{l}\text { Flow(seconds) - } \\
\text { After Exercise }\end{array}$ & 26.20 & 25 & 12.503 & 2.501 \\
\hline
\end{tabular}

Fig 4 tabular column representing mean with respect to flow rate of saliva

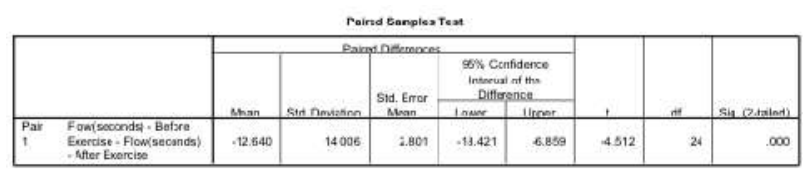

Fig 5 tabular column representing paired samples t test with respect to flow rate of Saliva

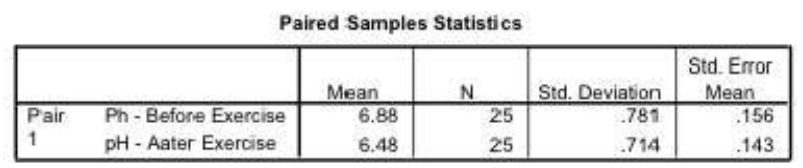

Fig 6 tabular column representing mean with respect to $\mathrm{pH}$ of saliva

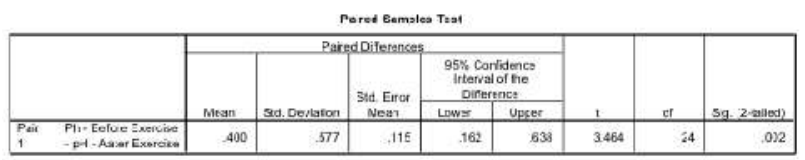

Fig 7 tabular column representing paired samples t test with respect to $\mathrm{pH}$ of saliva

\begin{tabular}{|l|r|r|r|}
\hline \multicolumn{1}{|c|}{ Chi-Square Tests } \\
& \multicolumn{1}{|c|}{ Value } & df & $\begin{array}{c}\text { Asymp. Sig. } \\
\text { (2-sided) }\end{array}$ \\
\hline Pearson Chi-Square & 3.625 & 4 & .459 \\
Likelihood Ratio & 3.326 & 4 & .505 \\
Linear-by-Linear & .915 & 1 & .339 \\
Association & 8.600 & 3 & .035 \\
McNemar-Bowker Test & 25 & & \\
N of Valid Cases & & & \\
\hline
\end{tabular}

a. 7 cells ( $77.8 \%$ ) have expected count less than 5 . The minimum expected count is .24 .

Fig 8 Tabular column representing chi square test with respect to viscosity of saliva

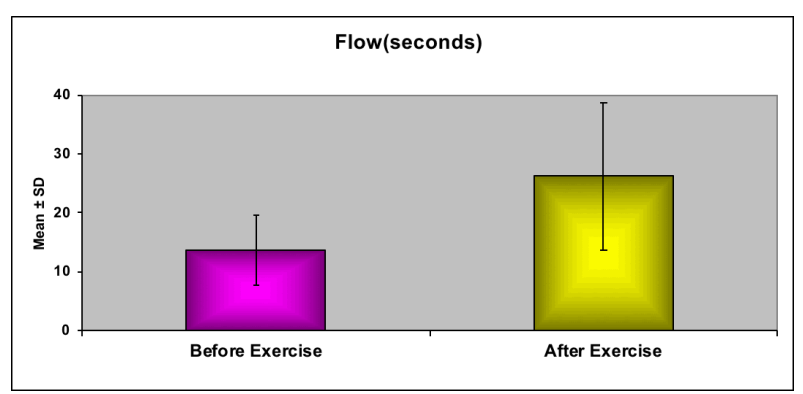

Fig 9 bar chart representing flow

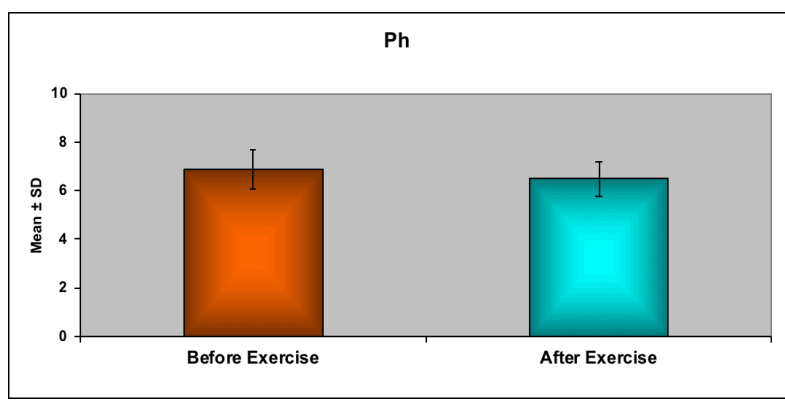

Fig 10 bar chart representing $\mathrm{pH}$

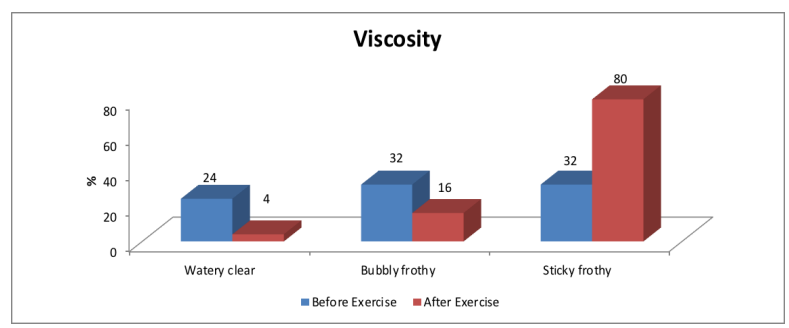

Fig 11 bar chart representing viscosity

\section{DISCUSSION}

Increase in salivary viscosity has been suggested in previous studies [13] and in our study it has been observed that $80 \%$ of the people had sticky frothy saliva after exercise, which 
implies an increase in the viscosity of saliva after exercise. In a study by C.A. Horswill et al, the post exercise flow rate of saliva wasn't different on consumption of sports drinks, but increased with consumption of water. And depending on the beverage consumed after exercise, the $\mathrm{pH}$ varied (highest for water and lowest for home-made drinks like lemon juice) [14] In our study there has been a statistically significant increase in time for flow of saliva and decrease in $\mathrm{pH}$ observed after exercise. Since the sample size was limited, further studies with larger sample sizes may yield more accurate results.

\section{CONCLUSION}

Use of Saliva in laboratory analysis, has a great potential, though standardisation of certain variables like system of collection, analyte to be quantified and schedules for collection, direct volume quantification, sample recovery and prevention of contamination is required.[15] There are various physiological variations in the saliva as observed in the study. Normally, the physiological alterations are overlooked, and research has been thriving only in the pathology of diseases. But it has to be kept in mind that physiological alterations like these, and the fact that people tend to consume beverages like energy drinks and juices after exercise, that further reduce their salivary $\mathrm{pH}$ levels, which will have a profound impact on the time taken by the oral cavity to recover to its normal conditions. These variations may predispose to plaque accumulation and initiation of dental caries.

\section{References}

1. Colcombe, S.J., et al. (2004) Cardiovascular Fitness, Cortical Plasticity, and Aging. Proceedings of the National Academy of Sciences of the United States of America, 101 , 3316-3321. http://dx.doi.org/10.1073/pnas.0400266101

2. Foss, M.L. and Keteyian, S.J. (1998) Fox's Physiological Basis for Exercise and Sport. 6th Edition, McGraw-Hill, Boston.

3. Mougios, V. (2006) Exercise Biochemistry. Matz. K., Ed., Human Kinetics, Champaign, Illinois, 332.

4. Christine Lo Bue-Estes et al.(2016) Changes in Salivary and Plasma Markers during and Following Short-Term Maximal Aerobic Exercise Assessed during Cognitive Assessment.

5. Bortolini, M.J.; De Agostini, G.G.; Reis, I.T.; Lamounier, R.P.; Blumberg, J.B.; Espindola, F.S. Total protein of whole saliva as a biomarker of anaerobic threshold. Res. Q. Exerc. Sport 2009, 80, 604-610. [CrossRef] [PubMed]
6. De Oliveira, V.; Bessa, A.; Lamounier, R.P.; de Santana, M.G.; de Mello, M.T.; Espindola, F.S. Changes in the salivary biomarkers induced by an effort test. Int. J. Sports Med. 2010, 31, 377-381. [CrossRef] [PubMed]

7. Bocanegra, O.L.; Diaz, M.M.; Teixeira, R.R.; Soares, S.S.; Espindola, F.S. Determination of the lactate threshold by means of salivary biomarkers: Chromogranin A as novel marker of exercise intensity. Eur. J. Appl. Physiol. 2012, 112, 3195-3203. [CrossRef] [PubMed]

8. Kunz, H.; Bishop, N.C.; Spielmann, G.; Pistillo, M.; Reed, J.; Ograjsek, T.; Park, Y.; Mehta, S.K.; Pierson, D.L.; Simpson, R.J. Fitness level impacts salivary antimicrobial protein responses to a single bout of cycling exercise. Eur. J. Appl. Physiol. 2015, 115, 1015-1027. [CrossRef] [PubMed]

9. Ligtenberg, A.J.; Brand, H.S.; van den Keijbus, P.A.; Veerman, E.C. The effect of physical exercise on salivary secretion of MUC5B, amylase and lysozyme. Arch. Oral Biol. 2015, 60, 1639-1644. [CrossRef] [PubMed]

10. Chatterton, R.T., Jr.; Vogelsong, K.M.; Lu, Y.C.; Ellman, A.B.; Hudgens, G.A. Salivary $\alpha$-amylase as a measure of endogenous adrenergic activity. Clin. Physiol. 1996, 16, 433-448. [CrossRef] [PubMed]

11. Bosch, J.A.; Brand, H.S.; Ligtenberg, T.J.M.; Bermond, B.; Hoogstraten, J.; Nieuw Amerongen, A.V. Psychological stress as a determinant of protein levels and salivary-induced aggregation of Streptococcus gordonii in human whole saliva. Psychosom. Med. 1996, 58, 374-382. [CrossRef] [PubMed]

12. Ljungberg, G.; Ericson, T.; Ekblom, B.; Birkhed, D. Saliva and marathon running. Scand. J. Med. Sci. Sports 1997, 7, 214-219. [CrossRef] [PubMed]

13. Dawes, C. The effects of exercise on protein and electrolyte secretion in parotid saliva. J. Physiol. 1981, 320, 139-148. [CrossRef] [PubMed]

14. C.A. Horswill et al, Effect of Exercise and Fluid Consumption on Salivary Flow and $\mathrm{pH}$. Int J Sports Med 2006; 27(6): 500-504

15. Lázaro Alessandro Soares Nunes et al. Saliva as a diagnostic fluid in sports medicine: potential and limitations. J Bras Patol Med Lab, v. 49, n. 4, p. 247255, agosto 2013.

\section{How to cite this article:}

Prema Sivakumar and Gifrina Jayaraj (2017) ' Effect of Exercise on Saliva Flow, Viscosity And pH', International Journal of Current Advanced Research, 06(04), pp. 3091-3093.

DOI: http://dx.doi.org/10.24327/ijcar.2017.3093.0190 